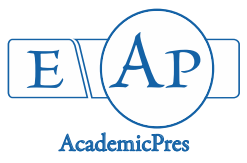

Habu MA et al. (2021)

Notulae Scientia Biologicae 13(1):10890

DOI: $10.15835 / \mathrm{nsb} 13110890$

Research Article

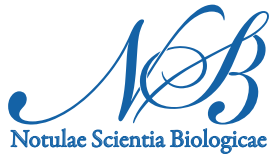

\title{
Health risk assessment and heavy metal bioaccumulation in vegetables irrigated with waste water in Kano State, Nigeria
}

\author{
M.A. HABU ${ }^{1}$, Usman BAWA ${ }^{1}$, Saheed I. MUSA ${ }^{2 *}$ \\ ${ }^{1}$ Bayero University Kano, Faculty of Life Sciences, Kano State, Nigeria; \\ Khaliphergml@gmail.com; ubawa.bio@buk.edu.ng; \\ ${ }^{2}$ Admiralty University of Nigeria, Faculty of Science, Department of Biological Sciences, Delta State, Nigeria; \\ Musa-biology@adun.edu.ng ("corresponding author)
}

\begin{abstract}
Intake of vegetables grown in heavy metals contaminated soils is one of the most common food chain routes for exposure of human. For this purpose, this research aimed at evaluating the concentration of heavy metals (cadmium-Cd, lead-Pb and zinc- $\mathrm{Zn}$ ) in vegetables such as spinach $(\mathrm{S})$, lettuce $(\mathrm{L})$, and onion $(\mathrm{O})$, irrigated with two different wastewater sources in Kano State Nigeria. Atomic Absorption Spectrophotometric analysis (AAS) was used in this research to determine the metal levels. $\mathrm{Zn}(0.17-0.12 \mathrm{mg} / \mathrm{l})$ was detected in the wastewater, as well as in the irrigated soil $(8.36-33.64 \mathrm{mg} / \mathrm{kg})$, while $\mathrm{Cd}$ and $\mathrm{Pb}$ were not detected in both the wastewater and irrigated soils. Furthermore, between $(1.50-27.05 \mathrm{mg} / \mathrm{kg})$ of $\mathrm{Zn}$ was detected in the assayed vegetables $(\mathrm{S}, \mathrm{L}$ and $\mathrm{O})$. However, there was no significant difference $(\mathrm{p}<0.05)$ between the $\mathrm{Zn}$ content of the two wastewater sites. Lactuca sativa was observed to have the highest $\mathrm{Zn}$ concentration $(27.5 \mathrm{mg} / \mathrm{kg})$ in site A, while Spinacia oleracea had the lowest $\mathrm{Zn}$ concentration $(1.5 \mathrm{mg} / \mathrm{kg})$. $\mathrm{Zn}$ levels in all the samples analysed in this study were below the permissible limit of $100 \mathrm{mg} / \mathrm{kg}$ in vegetables, $50 \mathrm{mg} / \mathrm{kg}$ in soil and $5 \mathrm{mg} / \mathrm{l}$ in wastewater set by $\mathrm{FAO} / \mathrm{WHO}$. However, $\mathrm{Pb}$ and $\mathrm{Cd}$ were not detected in all the samples. Bioaccumulation factor was found ranging from $0.32-41.17 \mathrm{mg} / \mathrm{kg}$ and the pollution index ranged from $\left(0.46-1.80 \mu \mathrm{g} \mathrm{g}^{-1}\right)$. This indicated potential health risk from $\mathrm{Zn}$ in people who are consuming these vegetables for long period of time due to biomagnification. This research suggested that frequent test should be carried out to monitor the accumulation and, farmers should be sensitized on the importance of treating irrigation water before agricultural usage.
\end{abstract}

Keywords: bioaccumulation; health risk assessment; vegetables; wastewater

\section{Introduction}

Shortage of irrigation water, especially in the tropical savannah regions of Nigeria have affected crop production. This problem became serious because of the increasing urbanization and industrialization in this region. In order to improve crop productivity through improved irrigation, local farmers resulted to utilizing immense amount of wastewaters released from industries for watering vegetables, most especially in industrial regions, due to water scarcity issues (Mashiatullah et al., 2005; Hamid et al., 2016). Wastewater have been documented to contain heavy metals such as zinc $(\mathrm{Zn})$, iron $(\mathrm{Fe})$, lead $(\mathrm{Pb})$, copper $(\mathrm{Cu})$, cadmium $(\mathrm{Cd})$ and

Received: 26 Jan 2021. Received in revised form: 08 Feb 2021. Accepted: 17 Feb 2021. Published online: 22 Feb 2021.

From Volume 13, Issue 1, 2021, Notulae Scientia Biologicae journal will use article numbers in place of the traditional method of continuous pagination through the volume. 
nickel $(\mathrm{Ni})$ among other chemicals. The concentration of these chemicals found in wastewater depends on the nature of the industry discharging the wastewater. Long term use of wastewater for irrigation have resulted in heavy metal build up in farming soils and vegetables (Chen et al., 2005; Sharma et al., 2007; Fatoba et al., 2012; Saini et al., 2014; Ugya et al., 2017) in different parts of the world.

In Kano state for example, wastewater is most times used for continuous irrigation of crops, especially vegetables such as lettuce, spinach, and onions. Aside water scarcity, easy accessibility, disposal problems and low rainfall are some of the reasons why local farmers opt for wastewater in growing vegetables in this area (Najam et al., 2015). Although there exist various clean-up strategies for treating wastewater, only few cares to treat the wastewater before usage. Growing soils usually serves as a substrate for plants therefore, presence of heavy metals in growing soils can easily be absorbed by the plants, leading to bioaccumulation and biomagnification in vegetables. Health complications in human and animals can occur by the intake of crops and vegetables grown with heavy metals containing water or substrate because leafy vegetables have high capacity to uptake and bioaccumulate heavy metals in their different parts (Alam et al., 2003).

Human health complications such as intrauterine growth retardation and upper gastrointestinal cancer and among others have been linked to heavy metals toxicity. Heavy metals such as copper, arsenic and zinc have also been known to cause diseases such as diarrhea, stomatitis, tremor, vomiting and poisoning (McCluggage, 1991; Cempel and Nikel, 2006; Oves et al., 2016). Based on the possible health risk owing to heavy metals intake and accumulation strength of vegetables, this study was therefore conducted to evaluate heavy metals levels in wastewater, soil, and commonly consumed vegetables after irrigation with wastewater of Fagge and Zawaciki wastewater sources. This is because these wastewater sources are the largest and first receivers of industrial and household's effluent in Fagge Local Government and Kumbotso Local Government Areas of Kano State, Nigeria. Bioaccumulation factor and pollution index were also determined to predict the associated health risk.

\section{Materials and Methods}

\section{Water sampling, handling, and analysis}

Water samples were obtained randomly from Fagge wastewater source at Fagge Local Government Area of Kano State and Zawaciki wastewater source at Kumbotso Local Government Area of Kano State. The sample were collected from three zones and care was taken to ensure that the wastewater collected is within the water source and soils that the local farmers used in growing the sample vegetables. The test vegetables and soils were collected around Fagge and Kumbotso Local Government Area of Kano State. Thirty samples (15 from each source) were taken in high density polyethylene bottles HDPE of $250 \mathrm{ml}$ and sterilized with $\mathrm{HNO}_{3}$ as reported by Siddique et al., 2014). The sample bottles were introduced into the water at $10 \mathrm{~cm}$ and allow to fill. The $\mathrm{HNO}_{3}$ acid was added so that the water samples would be preserved following (Khan et al., 2013). The samples obtained were filtered by using a Whatman 42 paper and then stored in storage flasks as reported by (Rehman et al., 2014; Siddique et al., 2014). The metallic levels ( $\mathrm{Zn}, \mathrm{Pb}$ and $\mathrm{Cd}$ ) of the water were evaluated using atomic absorption spectrophotometer (AAS). Standards were prepared with distilled water as matrix for every metal (Saini et al., 2014).

\section{Soil sampling and analysis}

Soil samples $(5 \mathrm{~g})$ at the rhizosphere of vegetables $(0-15 \mathrm{~cm})$ were collected separately from 3 zones on the farmland at each irrigation sites (A and B) by using a spiral auger of $2.5 \mathrm{~cm}$ diameter, following Khan et al. (2013). The soil samples were cleared by removing unrequired particles and air dried in a clean room to avoid contamination. The soils were then crushed and sieved through a $600 \mu \mathrm{m}$. The sieved samples were then stored in plastic jars following (Hamid et al., 2016). About $2.5 \mathrm{~g}$ of the soil sample was taken and added $50 \mathrm{ml}$ of 
DTPA solution. The mixture was constantly shacked for 2 hours using a shaker and filtered using Whatman 42 paper following (Al-Jaboobi et al., 2014).

A blank test was run using a sample that contains all substances excluding soil. The levels of $\mathrm{Zn}, \mathrm{Pb}$ and Cd were analyzed using AAS (Shimadzhu-7000, Japan) with respective hollow cathode lamp.

\section{Plant sampling and analysis}

Matured leaves of vegetables (Allium cepa, Lactuca sativa, and Spinacia oleracea) were obtained at harvesting stage in three different zones each from the two sites (A and B). The samples were cleared off impurities and bacterial using distilled water and then air dried. The sample were crushed to increase the surface area as seen in Hamid et al. (2016). A dry matter sample of $1 \mathrm{~g}$ was weighed into $250 \mathrm{ml}$ beaker, a $10 \mathrm{ml}$ analytical grade acids mixture containing $\mathrm{HNO}_{3}: \mathrm{HCIO}_{4}$ in the ratio 5:1 was added to the sample. Samples were then digested at a temperature of $190{ }^{\circ} \mathrm{C}$ for 1.5 hour and allowed to cool. Digested samples were filtered using Whatman No. 1 filter paper and solution was made up to final volume in a volumetric flask with distilled water. Heavy metals ( $\mathrm{Zn}, \mathrm{Pb}$ and $\mathrm{Cd}$ ) levels were detected by AAS. Guidelines for heavy metals acceptable limits in vegetables were adopted from FAO- WHO (2007).

Metal pollution index (MPI)

Metal Pollution Index (MPI) was computed to analyse the heavy metal concentrations in the wastewater irrigated vegetables. This index obtained using the geometrical mean of concentrations of all the metals in the vegetables as described by (Ureso et al., 1997; Musa et al., 2019) following:

$\mathrm{MPI}=(\mu \mathrm{gg}-1)=(\mathrm{Cf} \times \mathrm{Cf} \times \ldots \ldots \ldots \times \mathrm{Cf} \mathrm{n}) 1 / \mathrm{n}$

Where $\mathrm{Cf}^{\mathrm{n}}=$ concentration of metal ' $\mathrm{n}$ ' in the sample.

Statistical analysis

Statistical analysis was observed using SPSS VERSION 16, measuring the mean and standard deviations. Concentrations of heavy metals were expressed as mean \pm SDM (Standard Deviation of the Mean) of five replicates. Data obtained were then subjected to analysis of variance (ANOVA) with values for $\mathrm{p} \leq 0.05$ considered significantly different. Results were presented in Tables.

\section{Results and Discussion}

\section{Heavy metal concentration in wastewater}

Table 1 showed the heavy metals levels $(\mathrm{Zn}, \mathrm{Pb}, \mathrm{Cd})$ in wastewater samples from the two sites ( $\mathrm{A}$ and $B$ ) in the three sample zones. The concentration of zinc taken from the two different wastewater locations of Kano State ranged from $0.12-0.17 \mathrm{mg} / \mathrm{l}$. The maximum mean zinc concentration $(0.17 \mathrm{mg} / \mathrm{l})$ was observed in Zone 1 of site $A$, while minimum zinc concentration $(0.11 \mathrm{mg} / \mathrm{l})$ was in sample taken from Zone 3 in site $A$. The order of zinc contents in all location was Zone $1 \mathrm{~A}>$ Zone $3 \mathrm{~B}>$ Zone $1 \mathrm{~B}>$ Zone $2 \mathrm{~A}$ and $\mathrm{B}>$ Zone $3 \mathrm{~A}$. Zinc concentration in all wastewater samples was below the permissible limits of both WHO and FAO. This is consistent with a study by Mustaq and Khan (2010) who investigated water samples from two factories areas and found $\mathrm{Zn}$ and other metals below the $\mathrm{WHO}$ permissible level. However, $\mathrm{Cd}$ and $\mathrm{Pb}$ were not detected in all the wastewater samples from all the assayed zones. Since heavy metals contents of wastewaters depend on production company and type of its by-products, the presence of $\mathrm{Zn}$ in the wastewater indicated that the company might have likely make use of $\mathrm{Zn}$ oxides in their production. Constant release of these untreated wastewater may increase the $\mathrm{Zn}$ content to toxic levels. Although, $\mathrm{Cd}$ and $\mathrm{Pb}$ were detected in wastewater from other sources in Lagos, this may be as a result of the nature of the wastewater source or pollution sources. (Jagtap et al., 2010). 
Table 1. Mean concentration of heavy metals $(\mathrm{mg} / \mathrm{l})$ in wastewater used in irrigation obtained from different zones in site $\mathrm{A}$ and $\mathrm{B}$

\begin{tabular}{|c|c|c|c|c|c|c|}
\hline \multirow{2}{*}{ Samples } & \multicolumn{3}{|c|}{ Site A } & \multicolumn{2}{c|}{ Site B } \\
\cline { 2 - 6 } & $\mathrm{Zn}$ & $\mathrm{Cd}$ & $\mathrm{Pb}$ & $\mathrm{Zn}$ & $\mathrm{Cd}$ & $\mathrm{Pb}$ \\
\hline Zone 1 & $0.17 \pm 0.0029^{\mathrm{a}}$ & $\mathrm{ND}$ & $\mathrm{ND}$ & $0.14 \pm 0.0019^{\mathrm{a}}$ & $\mathrm{ND}$ & $\mathrm{ND}$ \\
\hline Zone 2 & $0.12 \pm 0.0028^{\mathrm{a}}$ & $\mathrm{ND}$ & $\mathrm{ND}$ & $0.12 \pm 0.0042^{\mathrm{a}}$ & $\mathrm{ND}$ & $\mathrm{ND}$ \\
\hline Zone 3 & $0.11 \pm 0.00097^{\mathrm{a}}$ & $\mathrm{ND}$ & $\mathrm{ND}$ & $0.15 \pm 0.0023^{\mathrm{a}}$ & $\mathrm{ND}$ & $\mathrm{ND}$ \\
\hline WHO standard & $5 \mathrm{mg} / \mathrm{l}$ & & & $5 \mathrm{mg} / 1$ & & \\
\hline
\end{tabular}

NB: Mean \pm SD (in the same column) with same letters in superscripts were significantly same $(\mathrm{P} \leq 0.05)$. ND implies not detectable.

\section{Heavy metal concentration in wastewater irrigated soils}

Current experiment used the soil samples collected from the same spot where the test water was used to irrigate plants. This result was presented in Table 2 . The $\mathrm{Zn}$ content in the soils irrigated with wastewater from two different sites ranged between $11.145-33.64 \mathrm{mg} / \mathrm{kg}$. The concentration of $\mathrm{Zn}$ in soil $(33.64 \mathrm{mg} / \mathrm{kg})$ was obtained in site B where lettuce was planted, while the lowest zinc concentration was obtained from site A soil where onion was planted. This showed that heavy metals present in irrigation water can leach into the lower soil layers and may influence plant physiology. Other heavy metals such as $\mathrm{Cd}$ and $\mathrm{Pb}$ that were not detected in the wastewater were also not found in all the growing soils. The zinc concentration in all the growing soil were below the WHO standard for heavy metals in growing soils. This study contradicts the findings of Mahallapa et al. (2010) who investigated soil samples from wastewater irrigated areas around Solapur city, India and they found that the contents of zinc extracted was above WHO permissible values. This difference may be because of the contamination frequency or the physicochemical properties of the soil. Plant species growing in the farmland may also influence the level of pollutant present (Musa and Ikhajiagbe, 2020). This study also showed that irrigation water plays a role in influencing physico-chemical properties and structures of arable soils.

Table 2. Heavy metal concentration $(\mathrm{mg} / \mathrm{kg})$ of soils receiving wastewater

\begin{tabular}{|c|c|c|c|c|c|c|}
\hline \multirow{2}{*}{ Samples } & \multicolumn{3}{|c|}{ Site A } & \multicolumn{3}{c|}{ Site B } \\
\cline { 2 - 7 } & $\mathrm{Zn}$ & $\mathrm{Cd}$ & $\mathrm{Pb}$ & $\mathrm{Zn}$ & $\mathrm{Cd}$ & $\mathrm{Pb}$ \\
\hline Spinach soil & $8.36 \pm 0.27^{\mathrm{a}}$ & $\mathrm{ND}$ & $\mathrm{ND}$ & $23.90 \pm 2.26^{\mathrm{a}}$ & $\mathrm{ND}$ & $\mathrm{ND}$ \\
\hline Lettuce soil & $31.70 \pm 0.12^{\mathrm{b}}$ & $\mathrm{ND}$ & $\mathrm{ND}$ & $33.64 \pm 0.76^{\mathrm{b}}$ & $\mathrm{ND}$ & $\mathrm{ND}$ \\
\hline Onion soil & $11.145 \pm 0.15^{\mathrm{c}}$ & $\mathrm{ND}$ & $\mathrm{ND}$ & $32.36 \pm 0.27^{\mathrm{b}}$ & $\mathrm{ND}$ & $\mathrm{ND}$ \\
\hline WHO standard & $50 \mathrm{mg} / \mathrm{kg}$ & & & $50 \mathrm{mg} / \mathrm{kg}$ & & \\
\hline
\end{tabular}

NB: Mean $\pm S D$ (in the same column) with different letters in superscripts differ significantly $(\mathrm{p}<0.005)$. ND implies not detectable.

\section{Heavy metal concentration in wastewater irrigated vegetables}

The levels of heavy metals ( $\mathrm{Zn}, \mathrm{Pb}$ and $\mathrm{Cd}$ ) detected in the edible parts of the vegetables were shown in Table 3. The main sources of heavy metals to vegetables are the substrates used in growing them. In the present study, the concentration of $\mathrm{Zn}$ in different vegetables ranged from $27.5-1.5 \mathrm{mg} / \mathrm{kg}$. Among all vegetables assayed, Lactuca sativa (Lettuce) contained the maximum concentration of $\mathrm{Zn}(16.82 \mathrm{mg} / \mathrm{kg})$ from the two experimental sites (A and B) with the site A lettuce having the maximum $\mathrm{Zn}(27.5 \mathrm{mg} / \mathrm{kg})$ content. However, lowest $\mathrm{Zn}$ levels $(2.63 \mathrm{mg} / \mathrm{kg}$ ) was detected in Spinacia oleracea (spinach) obtained from the two experimental sites (A and B), with the spinach from site $A$ recording the lowest $\mathrm{Zn}$ content. The morphology and physiology of vegetables for heavy metal usage is different. This may be the reason for variations in heavy metal concentration in different vegetables (Kumar et al., 2009). Variations among vegetables in terms of $\mathrm{Zn}$ concentration may also be due to the difference in $\mathrm{Zn}$ content of the wastewater and the $\mathrm{Zn}$ composition of the soil along with plants' capability to uptake and accumulate the heavy metal. There was significant difference $(\mathrm{P} \leq 0.05)$ between the $\mathrm{Zn}$ content in all vegetables irrigated with $\mathrm{A}$ and $\mathrm{B}$ wastewater sources. The order of 
vegetables regarding $\mathrm{Zn}$ concentration was lettuce $>$ onion $>$ spinach. However, $\mathrm{Zn}$ content in all the vegetables were below the safe limits of $100 \mathrm{mg} / \mathrm{kg}$ set by WHO and FAO. Cd and Pb were not found in the vegetables, this is possible as owing to the results that showed $\mathrm{Cd}$ and $\mathrm{Pb}$ were not observed in the wastewater and the irrigated soil (Table 1 and 2).

Table 3. Mean concentration of heavy metals $(\mathrm{mg} / \mathrm{kg})$ in vegetables

\begin{tabular}{|c|c|c|c|c|c|c|c|}
\hline \multirow{2}{*}{ Common name } & \multirow{2}{*}{ Scientific name } & \multicolumn{3}{|c|}{ Site A } & \multicolumn{3}{c|}{ Site B } \\
\cline { 3 - 8 } & & $\mathrm{Zn}$ & $\mathrm{Cd}$ & $\mathrm{Pb}$ & $\mathrm{Zn}$ & $\mathrm{Cd}$ & $\mathrm{Pb}$ \\
\hline Spinach & Spinacia oleracea & $1.5 \pm 0.32^{\mathrm{a}}$ & $\mathrm{ND}$ & $\mathrm{ND}$ & $3.77 \pm 0.12^{\mathrm{a}}$ & $\mathrm{ND}$ & $\mathrm{ND}$ \\
\hline${ }^{*}$ Lettuce & Lactuca sativa & $27.5 \pm 0.82^{\mathrm{b}}$ & $\mathrm{ND}$ & $\mathrm{ND}$ & $6.15 \pm 1.72^{\mathrm{c}}$ & $\mathrm{ND}$ & $\mathrm{ND}$ \\
\hline Onion & Allium cepa & $7.15 \pm 0.47^{\mathrm{c}}$ & $\mathrm{ND}$ & $\mathrm{ND}$ & $8.01 \pm 0.92^{\mathrm{c}}$ & $\mathrm{ND}$ & $\mathrm{ND}$ \\
\hline WHO/FAO $(2001)$ & & $100 \mathrm{mg} / \mathrm{kg}$ & & & $100 \mathrm{mg} / \mathrm{kg}$ & & \\
\hline
\end{tabular}

NB: Mean \pm SD (in the same column) with different letters in superscripts differ significantly $(\mathrm{P} \leq 0.05)^{*}$ shows highest accumulation.

Heavy metal bioaccumulation factor in wastewater irrigated vegetables

Since $\mathrm{Zn}$ was the only metal detected in the wastewater, soil and vegetables, a possible bioaccumulation factor was predicted and presented in Table 4 . The result showed $\mathrm{Zn}$ bioaccumulation factor in all the assayed vegetables irrigated with wastewater from the two experimental sites (A and B) in Kano State. Bioaccumulation factor is the ratio of heavy metal concentration in an organism to its surrounding concentration. Those samples with BAF $>1 \mathrm{mg} / \mathrm{kg}$ are heavy metals accumulators. From the results, lettuce, spinach, and onion all proved to be accumulators of $\mathrm{Zn}$. Onion proved to be the highest $\mathrm{Zn}$ accumulator in the both experimental sites, while spinach was the lowest accumulator in the both experimental sites. This high bioaccumulation factor in onion may be influenced by soil parameters such as $\mathrm{pH}$, organic matter, redox potential, CEC (Wang et al., 2013; Wilson et al., 2014; Ikhajiagbe et al., 2019). Zn show a significantly negative correlation with $\mathrm{pH}$ (García et al., 2009; Wang et al., 2013). The BAF in lettuce from the site A experimental site was below $1 \mathrm{mg} / \mathrm{kg}$ therefore its not proven as a bio accumulator. Aging factor and other soil properties may also affect heavy metals bioavailability in plants (Smolders et al., 2009; Ahmad and Goni, 2010). It may be predicted that if these plants were continuously irrigated with wastewaters, there is higher percentage of heavy metal pollution. Zinc toxicity causes neurological, gastrointestinal, and other physiological disorders (ATSDR, 2007).

Table 4. Estimated bioaccumulation factor $\mathrm{mg} / \mathrm{kg}$

\begin{tabular}{|c|c|c|}
\hline \multirow{2}{*}{ Samples } & Site A & Site B \\
\cline { 2 - 3 } & $\mathrm{Zn}$ & $\mathrm{Zn}$ \\
\hline Spinacia oleracea & 1.37 & 0.32 \\
\hline Lactuca sativa & 0.86 & 1.37 \\
\hline Allium cepa & 41.17 & 2.47 \\
\hline
\end{tabular}

NB: BAF $>1$ indicate higher accumulation of metal.

\section{Vegetables contamination and the implication for human health}

Due to the increasing consumption of vegetables irrigated with waste water especially in urban areas where waste water practices are still unchecked and the likely health impacts, there is a serious need for quantification of human risk assessment of consuming waste water irrigated vegetables. Pollution index (Table 5 ) is considered to be effective and precise method for monitoring heavy metal adverse effect of wastewater irrigated vegetables (Ureso et al., 1997). 
Table 5. Estimated pollution index $\left(\mu \mathrm{g} \mathrm{g}^{-1}\right)$

\begin{tabular}{|c|c|c|}
\hline \multirow{2}{*}{ Samples } & \multicolumn{2}{|c|}{ Pollution index } \\
\cline { 2 - 3 } & \multicolumn{2}{|c|}{ Zn } \\
\cline { 2 - 3 } & Site A & Site B \\
\hline Spinacia oleracea & 0.81 & 0.80 \\
\hline Lactuca sativa & 0.82 & 0.46 \\
\hline Allium cepa & 1.80 & 1.47 \\
\hline
\end{tabular}

NB: Pollution index $>1$ indicate higher level of contamination.

The highest metal pollution index was obtained from onion in site A. This may be due to the high BAF observed. This study is in line with a previous work by Khan et al. (2008) who researched on the health risk index of $\mathrm{Zn}$ in vegetable samples. They discovered Allium cepa and Lactuca sativa to be of higher $\mathrm{Zn}$ pollution index. All the vegetables have low, but growing pollution index of zinc. This suggested that if not minimized, these vegetables may lead to human health risk as a result of increasing build-up of heavy metals in their edible sections. Therefore, heavy metal contamination and accumulation in vegetables could be a matter of great concern for residents.

\section{Conclusions}

The presence of high concentration of heavy metals $(\mathrm{Zn}, \mathrm{Cd}$ and $\mathrm{Pb})$ irrigation water may lead to contamination of growing soil and can easily be uptake and accumulated by growing vegetables in their various body sections. Different vegetables showed different ability to absorb and accumulate heavy metals. In the present study, heavy metals concentration in irrigation water, soil and vegetables were all observed to be below permissible level of $\mathrm{WHO} / \mathrm{FAO}$ for water, soil, and vegetable. $\mathrm{Zn}$ was the only heavy metal detected in the wastewater, irrigated soils, and vegetables. The zinc levels were obtained to be below permissible level of WHO/FAO for water, soils, and vegetables. However, the high bioaccumulation factor observed in onion could lead to health hazard. The pollution index for onion from the two wastewater sites analysed exceeded 1 which may pose future cancer or neuro-intestinal health risk. Lettuce and spinach though indicated low level of contamination, continuous irrigation with wastewater may pose serious health challenge. Based on the current findings; it is recommended that irrigating vegetables with wastewater should be immediately discouraged and there should be a frequent assays of vegetable farms before being released for consumption. Farmers should be sensitizing on the importance of treating irrigation water before usage.

\section{Authors' Contributions}

HMA and UB designed the study, HMA carried out the research under the supervision of UB and MSI. MSI carried out the statistical analysis and interpretation of data. HMA and UB wrote the first draft. UB and MSI edited the final draft of the manuscripts. All authors read and approved the final manuscript.

\section{Acknowledgements}

The authors sincerely appreciate the immense contributions of staff and research students of Department of Biological Sciences, Bayero University, Kano in collaboration with research students from Department of Biological Sciences, Admiralty University of Nigeria, Delta State Nigeria. 


\section{Conflict of Interests}

The authors declare that there are no conflicts of interest related to this article.

\section{References}

Anderson PT, Devi ZHT, Diggins T, Stanford Z, Stone V, Roth S, ... Smith JB (2017). Nutrition analysis of cherry juice. Scientia Pomologica Journal 19:234-241. https://doi.org/10.7016/j.tnverpvoc.2010.102005

Ahmad JU, Goni MA (2010). Heavy metal contamination in water, soil, and vegetables of the industrial areas in Dhaka, Bangladesh. Environmental Monitoring and Assessment 166:347-357. https://doi.org/10.1007/s10661-009$1006-6$

Alam MG, Snow ET, Tanaka A (2003). Arsenic and heavy metal contamination of vegetables grown in Santa village, Bangladesh. Science of the Total Environment 308:83-96. https://doi.org/10.1016/S0048-9697(02)00651-4

AL-Jaboobi M, Zouahri A, Tijane M, Housni AE, Mennane Z, Yachou H, Bouksaim M (2014). Evaluation of heavy metals pollution in groundwater, soil and some vegetables irrigated with wastewater in the Skhirat region Morocco. Journal of Materials and Environmental Science 5(3):961-966.

ATSDR (2007). Toxicological profile for zinc. http://www.atsdr.cdc.goV/csem/zinc/znzinc2

Cempel M, Nikel G (2006). Nickel: a review of its sources and environmental toxicology. Polish Journal of Environmental Studies 15(3):375-382.

Chen Y, Wang C, Wang Z (2005). Residues and source identification of persistent organic pollutants in farmland soils irrigated by effluents from biological treatment plants. Environment International 31: 778-783. https://doi.org/10.1016/j.envint.2005.05.024

Fatoba PO, Ogunkunle CO, Oyedeji AA, Oladimeji OO (2012). Assessment of heavy metal contents of Lycopersicum esculentum (tomato) and Capsicum chinense (pepper) irrigated with treated and untreated detergent and soap wastewaters. Ethiopian Journal of Environmental Studies and Management 5(4-1):506-510. https//doi.org/10.4314/ejesm.v5i4.S10

García I, Diez M, Martín F, Simón M, Dorronsoro C (2009). Mobility of arsenic and heavy metal in a sandy-loam textured and carbonated soil. Pedosphere 19:166-1755. https://doi.org/10.1016/S1002-0160(09)60106-5

Hamid A, Riaz H, Sana A, Ahmad SR (2016). Heavy metal contamination in vegetables, soil and water and potential health risk assessment. American-Eurasian Journal of Agricultural \& Environmental Sciences 16(4):786-794.

Ikhajiagbe B, Musa SI, Okeme JO (2019). Effect of changes in soil cation exchange capacity on the reclamation of lead by Eleusine indica (L.) Gaertn. FUDMA Journal of Sciences 3(4):176-183.

Jagtap MN, Kulkarni MV, Puranik PR (2010). Flux of heavy metal in soils irrigated with urban waste water. AmericanEurasian Journal of Agricultural \& Environmental Sciences 8(5):487-493.

Khan A, Javid S, Muhmood A, Mjeed T, Niaz A, Majeed A (2013). Heavy metal status of soil and vegetables grown on peri-urban area of Lahore district. Plant Soil and Environment 32(1):49-54.

Khan S, Cao Q, Zheng Y, Huang Y, Zhu Y (2008). Health risk of heavy metals in contaminated soils and food crops irrigated with wastewater in Beijing, China. Environmental Pollution 152:686-692. https://doi.org/10.1016/j.envpol.2007.06.056

Kumar A, Sharma I, Varshney S, Verma P (2009). Heavy metals contamination of vegetable foodstuffs in Jaipur (India). Electronic Journal of Environmental, Agricultural and Food Chemistry 8(2):96-101.

Mashiatullah RA, Qureshi M, Niaz A, Javed T, Nisar A (2005). Biological quality of ground water in Rawalpindi Islamabad. The Environmental Monitoring 5:13-18.

McCluggage D (1991). Heavy metal poisoning. NCS magazine. The bird hospital, CO, USA.

Mohallapa N, Kulkami M, Purranik P (2010). Flux of heavy metals in soils irrigated with urban wastewaters. AmericanEurasian Journal of Agricultural \& Environmental Sciences 8(5):487-493.

Musa SI, Ikhajiagbe B (2020). Assessment of physico chemical properties of ferruginous ultisol in Benin City, Edo Statepossible impact on Plant distribution. Studia Universitatis Vasile Goldis Seria Stiintele Vietii 30(2):88-95.

Musa SI, Awayewaserere KO, Njoku KL (2019). Effects of dump site soil on the leaf structures of Luffa cylindrical(Sponge gourd) and Amaranthus viridis (Green Amaranth). Journal of Applied Sciences and Environmental Management 23(2):307-311. https://dx.doi.org/10.4314/jasem.v23i2.17 
Mushtaq N, Khan K (2010). Heavy metals contamination of soils in response to wastewater irrigation in Rawalpindi region. Pakistan Journal of Agricultural Sciences 47(3):215-224.

Najam S, Nawaz R, Ahmad S, Ehsan N, Khan MM, Nawaz MH (2015). Heavy metals contamination of soils and vegetables irrigated with municipal wastewater: A case study of Faisalabad. Pakistan Journal of Environment and Agricultural Sciences 4:6-10.

Oves M, Khan S, Qari H, Felemban N, Almeelbi A (2016). Heavy metals: biological importance and detoxification strategies. Journal of Bioremediation and Biodegradation 7(2):23-29. https://doi.org/10.4172/21556199.1000334

Rehman K, Ashraf S, Rashid U, Ibrahim M, Hina S, Iftikhar T, Ramzan S (2014). Comparison of proximate and heavy metal contents of vegetables grown with fresh and wastewater. Pakistan Journal of Botany 45(2):391-400.

Saini M, Sharma KC, Sharma M (2014). Study of heavy metal accumulation in spinach irrigated with industrial waste water of Bhiwadi industrial area, Rajasthan. Research Journal of Biological Sciences 2:66-72.

Sharma R, Agarwal M, Marshall F (2007). Heavy metals contamination of soil and vegetables in suburban areas of Varanasi, India. Ecotoxicology and Environmental Safety 66:258-266. https://doi.org/10.1016/j.ecoenv.2005.11.007

Siddique K, Ali S, Farid M, Sajid S, Aslam A, Ahmad R, ... Nazir MM (2014). Different heavy metal concentrations in plants and soil irrigated with industrial / sewage waste water. International Journal of Environmental Monitoring and Analysis 2(3):151-157. https://doi.org/10.11648/j.ijema.20140203.14

Smolders E, Oorts K, Van Sprang P, Schoeters I, Janssen CR, McGrath SP, McLaughlin MJ (2009). Toxicity of trace metals in soil as affected by soil type and aging after contamination: using calibrated bioavailability models to set ecological soil standards. Environmental Toxicology and Chemistry: An International Journal 28:633-1642. https://doi.org/10.1897/08-592.1

Ugya AY, Imam TS, Agamuthu P (2017). The effect of heavy metal air pollution arising from local metallurgical activities on albino rat. American Journal of Preventive Medicine and Public Health 1(1):10-19. htpps://doi.org/10.5455/ajpmph.280304

Ureso J, Regalado EG, Gracia I (1997). Trace elements in bivalve mollusks Ruditapes decussates and Ruditapes phillippinarum from Atlantic Coast of Southern Spain. Environment International 23(3):291-298. https://doi.org/10.1016/S0160-4120(97)00030-5

Wang C, Yang Z, Yuan X, Browne P, Chen L, Ji J (2013) The influences of soil properties on Cu and Zn availability in soil and their transfer to wheat (Triticum aestivum L.) in the Yangtze River delta region, China. Geoderma 193:131-139.

WHO/FAO (2007). Joint FAO/WHO. Food Standard Programme Codex Alimentarius Commission $13^{\text {th }}$ M Session. Report of the Thirty-Eight Session of the Codex Committee on Food Hygiene. Houston, United States of America, ALINORM 07/30/13.

Wilson SC, Tighe M, Paterson E, Ashley PM (2014). Food crop accumulation and bioavailability assessment for antimony (Sb) compared with arsenic (As) in contaminated soils. Environmental Science and Pollution Research 21(20):11671-11681.
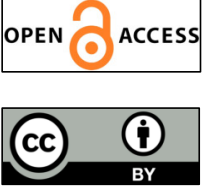

The journal offers free, immediate, and unrestricted access to peer-reviewed research and scholarly work. Users are allowed to read, download, copy, distribute, print, search, or link to the full texts of the articles, or use them for any other lawful purpose, without asking prior permission from the publisher or the author.

License - Articles published in Notulae Scientia Biologicae are Open-Access, distributed under the terms and conditions of the Creative Commons Attribution (CC BY 4.0) License.

(c) Articles by the authors; SHST, Cluj-Napoca, Romania. The journal allows the author(s) to hold the copyright/to retain publishing rights without restriction. 